AHP/ANP theory and its application in technological and economic development. The 90th anniversary of prof. Thomas I. Saaty

\title{
INTEGRATIVE MODEL FOR THE SELECTION OF A NEW PRODUCT LAUNCH STRATEGY, BASED ON ANP, TOPSIS AND MCGP: A CASE STUDY
}

\author{
Chin-Nung LIAO ${ }^{\mathrm{a}}$, Chih-Hsiang $\mathrm{LIN}^{\mathrm{b}}$, Yan-Kai FU' \\ a Department of Business Administration, China University of Science and Technology No. 245, \\ Sec. 3, Academia Rd., Nankang, Taipei, 115 Taiwan, R.O.C. \\ ${ }^{b}$ Department of Marketing and Distribution Management, Oriental Institute of Technology, \\ No. 58, Sec.2, Sihchuan Rd., Pan-Chiao City, Taipei County 22061,Taiwan, R.O.C
}

Received 15 January 2014; accepted 12 April 2015

\begin{abstract}
New product launch strategy is a key competitive advantage for a new product development. A new product launch is a multiple criteria decision-making problem, which involves evaluating different criteria or attributes in a strategy selection process. The purpose of this paper is to develop a qualitative and quantitative approach for the selection of a new product launch strategy. The current study proposes an integrated approach, integrating analytic network process, the technique for order preference by similarity to an ideal solution and multi-choice goal programming, which can be used to determine the best launch strategy for marketing problems. The advantage of this integrated method is that it enables the consideration of both tangible (qualitative) and intangible (quantitative) criteria as well as both "more/higher is better" (e.g., benefit criteria) and "less/lower is better" (e.g., cost criteria) in the launch strategy of a new product selection problem. To show the practicality and usefulness of this method, an empirical example of a watch company is demonstrated.
\end{abstract}

Keywords: launch strategy, new product development (NPD), analytic network process (ANP), technique for order preference by similarity to an ideal solution (TOPSIS), multi-choice goal programming (MCGP).

JEL Classification: C02, C61, L68, M11, M31.

\section{Introduction}

In an increasingly competitive environment, many businesses have adopted strategic planning techniques to achieve excellence in performance of new product development (NPD). For example, global markets have resulted in numerous businesses increasingly launching new products into foreign markets (Li, Lin 2014; Lockrey 2015). The implementation of

Corresponding author Chin-Nung Liao

E-mail:lliao@cc.cust.edu.tw 
appropriate new industrial product strategies plays an important role for market success. Marketers often conduct research to qualify the product concepts of NPD before they are launched in the market (Lam et al. 2013). NPD is an important driver of profitability, maintaining competitive advantage and ensuring company survival (Ernst 2002). Driven by intense international competition, rapidly changing customer needs, technological innovation, shortened product cycles and high $\mathrm{R} \& \mathrm{D}$ costs, managing and launching a new product has become a more crucial and complex issue (Biemans 2003). A number of issues consistently recur as related to new product success. One of the common factors identified is the impact of a new product launch strategy on success (Hultink et al. 1997).

Barczak (1995) noted that a firm's choices of a new product strategy, structure and process have interrelated effects on NPD performance. Ali et al. (1995) explored the relative impact of a new product innovation and market entrance strategy on the product life cycle time and initial market performance for small businesses. Droge and Calantone (1996) investigated the relationships among strategy, structure, performance and marketing environment in the context of NPD. Hultink et al. (1998), and Hultink and Robben (1999) developed a launch strategy and examined how decisions impact the performance of new product launches. Song et al. (2011) developed a model based on the resource-based view of firms, in which NPD uses external and internal resources to achieve positional advantages of product innovativeness, supplier involvement in production and product launch times. Chen et al. (2015) addressed external environments (i.e., the capabilities to influence government and to influence industry) can affect new product market performance.

However, a new product launch requires the largest commitment in terms of business resources, such as time and money, as well as human and social relationship resources. To be successful, the business resource of social capital, such as strategic partners, marketing channels, and business reputation, all play crucial roles in selecting launch strategies (Easingwood, Harrington 2002). Moreover, social capital factors induced by market characteristics exert a moderating influence on the relationships between firms' resources and strategy formulations (Aragon-Correa, Sharma 2003). Although previous studies have explored the interesting concept of new product performance and product launch strategies, there is still no consensus about how a launch strategy is selected and formulated for decision makers (DMs).

A new product launch is a critical stage of the market process, mainly because of the high risks and costs that it entails. Therefore, many scholars and managers consider the new product launch as the least well-managed phase of the entire marketing process (Bstieler 2012). The implementation of a NPD requires a series of activities. The more innovative the product is the more complicated is the process (Chwastyk, Kołosowski 2014). In addition, the launch strategy of new products is an important strategy adopted by many consumer goods companies and has been identified in previous research focusing on new product introduction to the market (Hsieh, Tsai 2007). However, the link between business resources and new product launch strategies and the effects of NPD quantification factors (e.g., marketing budget, R\&D expenditures, sales force size and numbers of channels) on the relationships among business resources and new product launch strategies have scarcely been examined in prior research. The purpose of this paper is to develop a qualitative and quantitative approach to formulating a model and selecting a new product launch strategy. 
A hierarchical multiple criteria decision-making (MCDM) approach is proposed. To show the practicality and usefulness of this model, an example is offered to validate this method.

In this study, an integrated method of analytic network process (ANP), the technique for order preference by similarity to ideal solution (TOPSIS) and the multi-choice goal programming (MCGP) model is proposed to help select a new product launch strategy. First, ANP is used to calculate the relative weight of each criterion. Second, TOPSIS is used to generate criteria closeness coefficients. Finally, based on the tangible and intangible constraints regarding the launch strategy, a MCGP model is formulated and solved to identify the best launch strategy. The integrated method is shown in Figure 1.

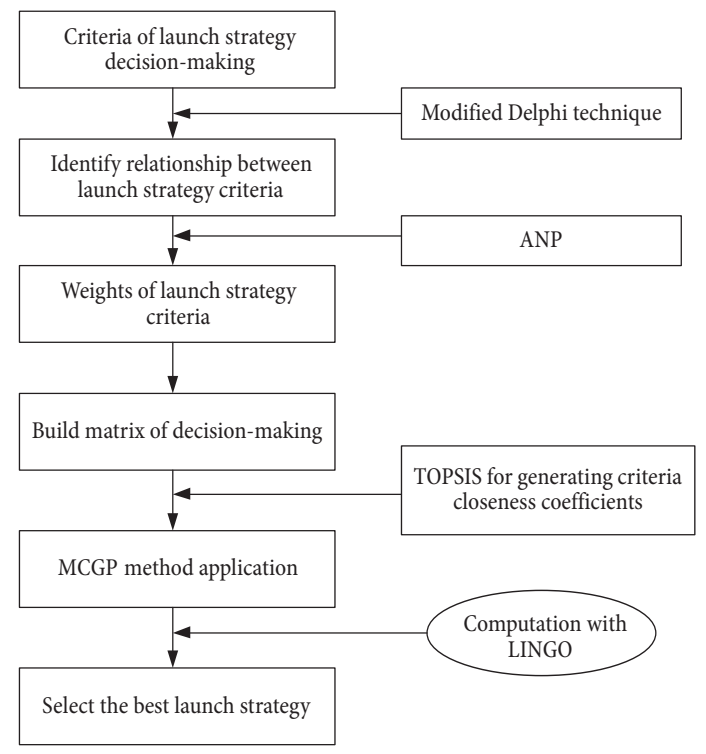

Fig. 1. The new product launch strategy decision-making procedure

The remainder of this study is structured as follows. Section 1 of this study reviews the literature pertaining to new product launch strategy and business resources and presents the marketing strategy evaluation framework and reviews the techniques used in the model. Section 2 introduces the ANP, TOPSIS, and MCGP methodology. Section 3 applies the integrated method to the launch strategy problems with a numerical example. Finally, the last Section provides the conclusions of the study.

\section{Literature review}

\subsection{New product launches strategy}

New product launch strategies have been applied in a number of ways. Launching new products to market quickly is a key success factor for acquiring a competitive business advantage. Banerjee and Soberman (2013) showed that firms' launch strategies are affected by 
the degree to which consumers think it's value (e.g., cost vs. value). The launch strategy for new products is costly, risky, time-consuming and not suitable for all companies (Hultink et al. 1997). Therefore, the challenge that product development managers face today is to identify the specific launch strategy that certain types of companies should follow (Hsieh, Tsai 2007). The launch timing strategies of entry into a market is a key factor for a company. Miles and Snow (1978) developed four strategic types based on the rate at which a firm changes its products or markets in response to its environment. Cooper (1985) identified launch strategy types that contribute to new product success based on NPD performance.

Barczak (1995) developed three strategic types based on the timing of entry: first to market, fast follower, and delayed entrant. Additionally, Barczak found that first-to-market firms use R\&D to a greater extent than either fast followers or delayed entrants. In addition, Barczak explored the relationship between the timing of the market entry and the performance of a new product and found that fast-follower firms reap significant economic advantages over first-to-market and later-entry firms; the performance order is fast-follower, first-to-market and later-entry firms. Hultink et al. (1997) has investigated innovation development methods, such as niche-market and price-skimming launch strategies that are the most successful strategies in terms of product performance.

Moreover, Kotler (2003) noted that in commercializing a new product, the market entry timing is critical. The company can consider three strategies. First entry: the firm entering a market usually enjoys the first-mover advantages of locking up key distributors and customers and gaining a leadership reputation. Parallel entry: the firm might time its entry to coincide with the competitor's entry. The market may pay more attention when two companies are advertising the new product. Late entry: the firm might delay its launch until after the competitor has entered. The competitor (e.g., first entry and parallel entry) will have borne most of the marketing expenditures (e.g., educating the customers). The competitor's product may reveal faults that the late entrant can avoid. The later entrant can also learn about the size of the market (Kotler 2003).

In contrast, Robinson et al. (1992) presented five types of new product launch strategies, including first entrant, other market pioneer, early follower, late entrant and marketing skills. According to the literature review on new product launch strategies and manager interviews, this research adopted Robinson's et al. (1992) definition of three new product launch strategies, which are as follows: First entrant (FE), Fast follower (FF), and Late entrant (LE) to market. Table 1 provides the evaluators with a consideration base for rating the launch strategy based on various criteria.

Table 1. Categories and definitions of new product launch strategies

\begin{tabular}{ll}
\hline \multicolumn{1}{c}{ Launch strategy } & \multicolumn{1}{c}{ Definition } \\
\hline First entrant (FE) & The first business to develop new products or services \\
\hline Fast follower (FF) & An early follower of the pioneer(s) in a still growing, dynamic market \\
\hline Later entry (LE) & A later entrant into a more established market situation \\
\hline
\end{tabular}




\subsection{Market characteristics}

The influence between market characteristics and new product launch strategies has been explored in extensive studies. Robinson and Fornell (1985), and Gatignon et al. (1990) addressed the relationship between market growth and business performance and found that market growth has a great influence on launch strategy decisions. Similarly, many NPD studies also identify positional market characteristics influence performance outcomes, including satisfaction, loyalty and market share (Song, Parry 1997). Furthermore, market competitiveness is another widely accepted characteristic that attracted the attention of researchers such as Gatignon et al. (1990); Lambkin (1992); Bowman and Gatignon (1995); Guitinan (1999); Hultink and Robben (1999); Hsieh and Tsai (2007); and Chwastyk and Kołosowski (2014).

In addition, the successful launch of new products has been influenced by market characteristics and firm's performance. Cooper (1994) addressed that thorough understanding of the competitive situation, the nature of the market and the customers' needs and wants is an essential component of new product success. NPD project-level success occurs along variety dimensions: customer-determined, financial/firm performance, market share, impact on the firm, and meeting objectives (Griffin, Page 1993; Cooper 1994). According to these studies, there are three market characteristics: market share/potential, firm performance and the number of competitors are distinguished as the most significant characteristics for strategy decision-making.

\subsection{Social capital}

Social capital is also an important resource that deserves attention during the strategy formulation from businesses aiming to launch new products (Hsieh, Tsai 2007) Social capital establishes a bond partners, which is characterized in the mutual feelings of attachment and trust (Uzzi 1996). In addition, social capital provides external networks for the discovery of opportunities, the testing of new product ideas, and the obtainment of resources (Lee et al. 2001). Most previous studies have investigated the concept, attributes and functions of social capital (Uzzi 1996; Hsieh, Tsai 2007; Su, Rao 2011). According to prior studies, social capital comprises of partnership-based linkages and sponsorship-based ones. The former includes ties to other enterprises (e.g., strategic alliance), venture capitalists (e.g., external financing), universities, research institutes and venture associations, while the latter consists of linkages with government agencies and commercial organization (Lee et al. 2001). Based on the mutual linkages and complementation, industrial clusters are usually established and competitive advantage is heightened (Porter 1980).

Drawing from the outstanding exposition reported by Nahapiet and Ghoshal (1998), social capital is defined as "the sum of the actual and potential resources available though, embedded within, and derived from the network of relationships possessed by an social or individual units" (Hsieh, Tsai 2007). Therefore, social capital supplies external networks for the discovery of chances, to the testing of NPD ideas, and to acquisition of resources. According to Hsieh and Tsai (2007)'s research, 33-47\% of all global technological or industrial new product design projects are completed by utilizing outsourcing or partner technologies. In sum social capital is offer in such strategic management decisions. 


\subsection{Technological capability}

Technological capability is the driving force of a business's new product innovation and consists of technological know-how, firm-internal capital, and knowledge engendered by $\mathrm{R} \& \mathrm{D}$, the sales force, and other technology-specific intellectual properties or patents protected by law (Lee et al. 2001; Hsieh, Tsai 2007). As the number of new products developed by new technologies has increased, the importance of the commercialization of new technology products has become crucial to firms in the successful delivery of new products launch (Cho, Lee 2013). For example, to obtain long-term benefit, many firms must continually make large investments in R\&D to increase their technological capability. Furthermore, new product projects were found to be decidedly balanced between technological versus R\&D activities (Cooper 1994). Song and Parry (1997) have addressed a significant positive correlation between new product success and (1) technological capability, which embrace $R \& D$, engineering, and production, and (2) the level of the business's marketing skills, which embrace marketing research, advertising and promotion, and sales force and distribution. Many new product studies emphasize the technical aspects of NPD process (Parry, Song 1994; Lam et al. 2013; Goodwin et al. 2014). Therefore, technological capability is an important strategic resource for businesses, particularly technological companies, to remain in the lead position.

\subsection{New product development organization}

Companies use NPD to send a message to target groups before the new product launch $(\mathrm{Su}$, Rao 2011). The successful launch of a new product plays an important part in helping companies to stay ahead of their competitors (Goodwin et al. 2014). Regarding NPD structure, Barczak (1995) has shown that project teams, R\&D teams, and product/marketing managers are the top three teams likely to be used by technological firms when undertaking NPD efforts. In addition, considering that regarding new launch strategies, the first-to-market firms have strong R\&D skills and technological leaders, these firms would use R\&D teams more intensively than the other launch strategies (Robinson et al. 1992). Several studies of NPD emphasize the importance of some different aspects of internal commitment. Internal commitment refers to the existence within the organization of a group of individuals who push a NPD project forward toward completion and successful commercialization (Song, Parry 1997). The internal commitment was found to have significant relationships with new product performance. Cooper (1994) investigated into new product success consistently cite interfaces between marketing and $\mathrm{R} \& \mathrm{D}$, co-ordination among key internal groups, multi-disciplinary inputs to the NPD project, and the role of teams and the team leader. Firms with a high new product performance used R\&D teams and product/marketing managers to a greater degree than low-performance firms when developing a new product (Barczak 1995).

\subsection{Marketing mix}

The marketing-mix strategy is another important factor for the success of a new product launch. The marketing literature describes a launch strategy as those decisions and activities 
necessary to present a product to its target market and to generate income from sales of the new product (Hultink et al. 1997). Marketing managers will consider that a new product launch occurs prior to making decisions on marketing mix and even prior to the product development. Marketing-mix decisions include the level, mix, and allocation of marketing efforts across tactical levels such as product branding, pricing, number of channels, distribution expenditures, sales force intensity (size), and promotion expenditures (Chiu et al. 2006). Moreover, producer services play an increasingly important role in providing final new products (Gao et al. 2011).

Based on literature as well as practical considerations, this study selected the criteria identified from previous literature, including Parry and Song (1994); Cooper (1994); Song and Parry (1997); Hsieh and Tsai (2007); Hultink et al. (1997) and Chiu et al. (2006), Goodwin et al. (2014) and interviews with experts. Nine experts participated in a group that applied the modified Delphi technique (see John 2011). The questionnaire was send by using e-mail; the criteria evaluation and selection of launch strategy were defined; the final criteria was extracted in whish a score of four on the Likert 5-point scale must be achieve; and the results were collected after passing three rounds of using the modified Delphi technique. Based on the results of group decision-making and modified Delphi technique that there are there are five criteria, including market characteristics (MC), social capital (SC), technological capability (TC), new product development organization (NO), and marketing $\operatorname{mix}(\mathrm{MM})$, as launch strategy evaluation criteria.

\section{Methodology}

\subsection{ANP method}

Analytic network process (ANP) is a general form of the analytical hierarchy process (AHP) first introduced by Saaty (1996). While the AHP use a unidirectional hierarchical relationship among decision levels, and the ANP enables interrelationships among the decision levels and attributes in a more general form. In place of a hierarchy, the ANP based system is a network that replaces single direction relationships with dependence and feedback (Saaty 1996). ANP methods are useful tools for evaluating the multi-criteria decision-making (MCDM) methods (Peng et al. 2011). ANP is a comprehensive decisionmaking technique that captures the outcome of dependence within and between clusters of elements (e.g., Wu et al. 2012). Due to the fact that the ANP can consider the interrelationships among elements in a problem setting, the use of the ANP in strategy selection has increased substantially in recent years (Kang et al. 2012). Saaty (1996) stated that the feedback method, a generalization of the idea of a hierarchy, is used to derive priorities in a system with interdependence influences.

Establishing an ANP model requires defining the elements and their assignment to clusters, as well as their relationships. Moreover, a supermatrix - a partitioned matrix of the interdependence influences among the elements - should be obtained according to these priority vectors. (Wu et al. 2010). The supermatrix concept resembles the Markov chain process. The supermatrix is derived from the limiting powers of the priorities to calculate 
the overall priority vectors; thus, the cumulative influence of each element on every other element with which it interacts is acquired (Saaty, Vargas 1998). Eq. (1) presents a standard form of a supermatrix of a hierarchy with three levels, which is used in this paper.

$$
\begin{aligned}
& \begin{array}{lll}
\mathrm{C}_{1} & \mathrm{C}_{2} & \mathrm{C}_{3}
\end{array} \\
& \mathrm{~W}_{\mathrm{h}}=\begin{array}{l}
C_{1} \\
C_{2} \\
C_{3}
\end{array}\left[\begin{array}{lll}
w_{11} & w_{12} & w_{13} \\
w_{21} & w_{22} & w_{23} \\
w_{31} & w_{32} & w_{33}
\end{array}\right] .
\end{aligned}
$$

Pairwise comparisons of the row components with respect to the column component are used to obtain an eigenvector, and this process produces an eigenvector for each column block. For increasing the power of a matrix will help obtain the relative long-term influences of the elements on one other (Lin, Tsai 2010). To achieve convergence of the importance weights, the supermatrix is increased to the power of $2 k+1$, where $k$ is an arbitrarily large number, and this new matrix is termed the limit supermatrix. If the matrix is irreducible and primitive, the limiting value is obtained by increasing $W_{\boldsymbol{h}}$ to powers such as $\lim _{\mathrm{k} \rightarrow \infty} W_{h}^{k}$ to obtain the global priority vectors.

Technique for order preference by similarity to an ideal solution (TOPSIS) method is one of the best-known approaches for solving multiple criteria decision-making (MCDM) problems. TOPSIS was first proposed by Hwang and Yoon (1981) and it is a widely accepted method to solve the MCDM problem because of its logic and its programmable computation procedure (Önüt et al. 2009). The concept of TOPSIS is that an alternative that is closest to the ideal solution and farthest from the negative-ideal solution in a multidimensional computing space is the optimal choice (Deng et al. 2000). Figure 2 explains the logical concept of TOPSIS by comparing Euclidean distances: $d_{2}<d_{1}<d_{3}$; thus, $A_{2}$ is closest to the ideal solution, and $A_{2}$ is the optimal solution (Lin et al. 2011). The TOPSIS procedure consists of the following steps:

Step 1. Build a decision matrix $(D)$ with values of criteria for alternative performances.

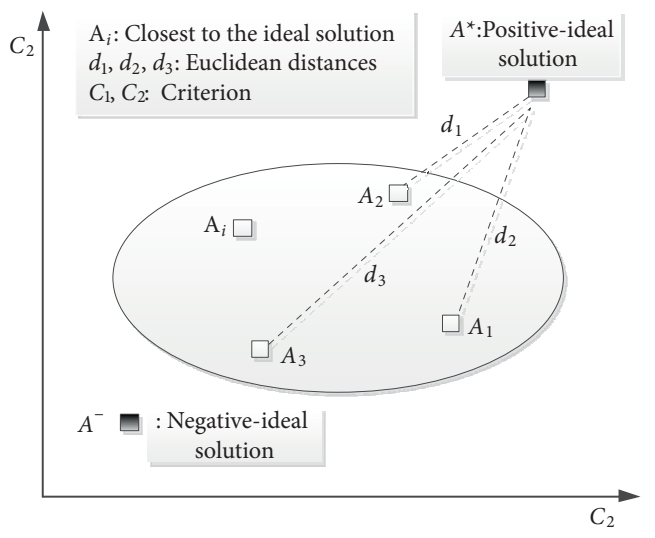

Fig. 2. The logic concept of the TOPSIS Source: Lin et al. (2011) 


$$
\begin{aligned}
& \begin{array}{llll}
\mathrm{C}_{1} & C_{2} & \cdots & C_{n}
\end{array} \\
& D=A_{2} A_{1}\left[\begin{array}{cccc}
x_{11} & x_{12} & \cdots & x_{1 n} \\
x_{21} & x_{22} & \cdots & x_{2 n} \\
\vdots & \vdots & \cdots & \vdots \\
x_{m 1} & x_{m 2} & \cdots & x_{m n}
\end{array}\right],
\end{aligned}
$$

where $x_{i j}$ denoted the performance of criterion $C_{i}$ for alternative $A_{i}$, given $i=1,2, \ldots, m$ and $j=1,2, \ldots, n$.

Step 2. Calculate the normalized decision matrix $R\left(=\left[r_{i j}\right]\right)$. The normalized value $r_{i j}$ can be calculated as follows:

$$
r_{i j}=x_{i j} / \sqrt{\sum_{j=1}^{J} x_{i j}^{2}} i=1,2, \ldots, m, j=1,2, \ldots, n .
$$

Step 3. Create the weighted normalized decision matrix.

The weighted normalized value $v_{i j}$ can be calculated as follows:

$$
v_{i j}=w_{j} * r_{i j}, i=1,2, \ldots, m, j=1,2, \ldots, n,
$$

where $w_{i}$ represents the weight of the $j$ th attribute or criterion as calculated by ANP, and $\sum_{j=1}^{n} w_{j}=1$.

Step 4. Determine the PIS $\left(A^{\star}\right)$ and the NIS $\left(A^{-}\right)$as follows:

$$
\begin{aligned}
& A^{*}=\left\{\left(\max _{i} v_{i j} \mid j \in C_{b}\right),\left(\min _{i} v_{i j} \mid j \in C_{c}\right)\right\}=\left(v_{1}^{*}, v_{2}^{*}, \cdots, v_{n}^{*}\right) ; \\
& A^{-}=\left\{\left(\min _{i} v_{i j} \mid j \in C_{b}\right),\left(\max _{i} v_{i j} \mid j \in C_{c}\right)\right\}=\left(v_{1}^{-}, v_{2}^{-}, \cdots, v_{n}^{-}\right),
\end{aligned}
$$

where $C_{b}$ is associated with benefit criteria, and $C_{c}$ is associated with cost criteria.

Step 5. Calculate the overall separation measures from the PIS and NIS.

The overall separation measure is calculated as follows:

and

$$
d_{i}^{*}=\sqrt{\sum_{j=1}^{J}\left(v_{i j}-v_{j}^{*}\right)^{2}}, i=1,2, \ldots, n,
$$

$$
d_{i}^{-}=\sqrt{\sum_{j=1}^{J}\left(v_{i j}-v_{j}^{-}\right)^{2}}, i=1,2, \ldots, n .
$$

Step 6. Calculate the relative closeness to the ideal solution.

The relative closeness coefficient of the alternative $A_{j}$ is defined as follows:

$$
C C_{i}^{*}=d_{i}^{-} /\left(d_{i}^{*}+d_{i}^{-}\right), i=1,2, \ldots, n .
$$

The index value of $C C_{i}^{*}$ lies between 0 and 1 . A larger index value is closer to the ideal solution for alternatives. 


\subsection{Multi-choice goal programming (MCGP) method}

Goal programming (GP) is an important technique to identify a set of satisfying solutions to MCDM problems. GP was first introduced by Charnes and Cooper (1961) and was further developed using various types of methods, such as Lexicographic GP, Weighted GP and MINMAX GP (Romero 2001). The purpose of GP is to minimize the unwanted deviations between the achievement of goals and their aspiration levels (Liao, Kao 2011). WGP can be expressed as follows:

$$
\begin{aligned}
& \operatorname{Min} \sum_{i=1}^{n} \mathrm{w}_{\mathrm{i}}\left|f_{i}(X)-g_{i}\right| \\
& \text { s.t. } X \in F \text { ( } F \text { is a feasible set }),
\end{aligned}
$$

where $f_{i}(X)$ is the linear function of the ith goal, $g_{i}$ is the aspiration level of the $i$ th goal and $w_{i}$ denotes the weight of $i$ th.

Eq. (10) represents a multiple WGP model and cannot be solved by linear programming (LP) approaches, which consider only one objective at a time or in which all objectives are measured in the same units (such as dollars). However, an organization often has more than one objective, and some objectives may relate to non-monetary objectives (Taylor 2004; Render et al. 2006). While WGP is capable of handling decision problems involving multiple goals, if the problem belongs to a multiple-choice objective, it becomes a MCGP problem that cannot be solved by current WGP approaches.

MCGP allows the decision-maker to set multi-choice aspiration levels for each goal to avoid underestimation of the decision. The rapid development of MCGP has led to significant diversity in models and methods. However, few studies have explored using MCGP to address real-world MCDM problems, such as a product launch strategy selection, which involve the conflict of criteria. In fact, the conflicts between criteria and the incompleteness of information make it very difficult for decision-makers to build a reliable mathematical model for the representation of their preference. A MCGP problem can be stated in the following model (Chang et al. 2014):

$$
\begin{aligned}
& \operatorname{Min} \sum_{i=1}^{n} w_{i}\left|f_{i}(X)-g_{i j}\right| \\
& \text { s.t. } g_{i j}=g_{i 1} \text { or, } g_{i 2} \text { or, } \ldots ., \text { or } g_{i m} \text {, } \\
& X \in F \text { ( } F \text { is a feasible set), }
\end{aligned}
$$

where $g_{i j}(i=1,2, \ldots, n$ and $j=1,2, \ldots, m)$ is the $j$ th aspiration level of the $i$ th goal, $g_{i j-1} \leq g_{i j} \leq g_{i j+1}$; all other variables are defined as in WGP.

MCGP can be reformulated as the following two alternative MCGP-achievement functions (Chang 2008). The first type: the more-the-better model is formulated as follows:

$$
\begin{aligned}
& \operatorname{Min} \sum_{i=1}^{n}\left[w_{i}^{d}\left(d_{i}^{+}+d_{i}^{-}\right)+w_{i}^{e}\left(e_{i}^{+}+e_{i}^{-}\right)\right] \\
& \text {s.t. } f_{i}(X)-d_{i}^{+}+d_{i}^{-}=y_{i}, i=1,2, \ldots, n ;
\end{aligned}
$$




$$
\begin{aligned}
& y_{i}-e_{i}^{+}+e_{i}^{-}=g_{i, \max }, i=1,2, \ldots, n \\
& g_{i, \min } \leq y_{i} \leq g_{i, \max } ; \\
& d_{i}^{+}, d_{i}^{-}, e_{i}^{+}, e_{i}^{-} \geq 0, i=1,2, \ldots, n ; \\
& X \in F \quad(F \text { is a feasible set }),
\end{aligned}
$$

where $d_{i}^{+}$and $d_{i}^{-}$are the positive and negative deviation attached to the $i$ th goal $\left|f_{i}(X)-y_{i}\right|$ in Eq. (14); $e_{i}^{+}$and $e_{i}^{-}$are the positive and negative deviation attached to $\left|y_{i}-g_{i, \max }\right|$ in Eq. (15); $w_{i}^{e}$ is the weight attached to the sum of the deviation of $\left|y_{i}-g_{i, \max }\right|$; all other variables are defined as in MCGP.

The second type: the less-the-better model is formulated as follows:

$$
\begin{aligned}
& \operatorname{Min} \sum_{i=1}^{n}\left[w_{i}^{d}\left(d_{i}^{+}+d_{i}^{-}\right)+w_{i}^{e}\left(e_{i}^{+}+e_{i}^{-}\right)\right] \\
& \text {s.t. } f_{i}(X)-d_{i}^{+}+d_{i}^{-}=y_{i}, i=1,2, \ldots, n \text {; } \\
& y_{i}-e_{i}^{+}+e_{i}^{-}=g_{i, \min }, i=1,2, \ldots, n ; \\
& g_{i, \min } \leq y_{i} \leq g_{i, \max } ; \\
& d_{i}^{+}, d_{i}^{-}, e_{i}^{+}, e_{i}^{-} \geq 0, i=1,2, \ldots, n ; \\
& X \in F(F \text { is a feasible set }),
\end{aligned}
$$

where $d_{i}^{+}$and $d_{i}^{-}$are the positive and negative deviations attached to the $i$ th goal $\left|f_{i}(X)-y_{i}\right|$ in Eq. (18); $e_{i}^{+}$and $e_{i}^{-}$are the positive and negative deviations attached to $\left|y_{i}-g_{i, \min }\right|$ in Eq. (19); $w_{i}^{e}$ is the weight attached to the sum of the deviation of $\left|y_{i}-g_{i, \text { min }}\right|$; all other variables are defined as in MCGP.

The integration model among AHP, ANP, linear programming (LP) and TOPSIS has been applied in a variety of selection problems. Ghodsypour and O'Brien $(1998,2001)$ applied the AHP and LP methods to propose a supplier selection model and surveyed several approaches including LP, non-linear programming, mixed-integer programming, GP and multi-objective programming in supplier selection processes. Gao and Tang (2003) developed a multi-objective LP model in the purchasing division of a large-scale steel plant. Guneri et al. (2009) adopted the fuzzy LP approach for a supplier selection problem in supply chain management. Lin et al. (2011) applied the ANP, TOPSIS and LP approaches to propose a supplier selection model. Liao (2013a) proposed an evaluation model using fuzzy TOPSIS and goal programming for a total quality management consultant selection.

However, the implications of these two approaches are different. While the objective of LP is to minimize the objective function directly, the objective of GP is to minimize the total deviations from the desired goals. In contrast, the deviational variables are typically the only variables in the objective function of a GP model, and the objective is to minimize the total of these deviational variables (Render et al. 2006). Lee and Kim (2000) applied ANP and GP for an interdependent information system project selection. Based on previous research of scholars and considering both tangible and intangible multiple-choice problems, this paper integrates the ANP, TOPSIS and MCGP model to solve the new product launch strategy selection. 
The final integrated MCGP can be shown as follows:

$$
\begin{aligned}
& \text { Min } \mathrm{Z}=p_{k}\left(C C_{j} d_{i}^{+}, C C_{j} d_{i}^{+}\right)+\left(e_{i}^{+}, e_{i}^{-}\right) \\
& \text {s.t. } a_{i j} x_{j}-d_{i}^{+}+d_{i}^{-}=y_{i} ; \\
& y_{i}-e_{i}^{+}+e_{i}^{-}=g_{i, \min } \text { or } g_{i, \max } ; \\
& g_{i, \min } \leq y_{i} \leq g_{i, \max } ; \\
& x_{j}+d_{i}^{-}=1 ; \\
& d_{i}^{+}, d_{i}^{-}, e_{i}^{+}, e_{i}^{-} \geq 0, i=1,2, \ldots, n, j=1,2, \ldots, m,
\end{aligned}
$$

where $x_{j}$ is the launch strategy; $a_{i j}$ is the $j$ th launch strategy using the closeness coefficient of the $i$ th business resources; and $y_{i}$ is the $i$ th available resource or limitation factor that must be considered in the selection decision; $p_{k}$ denotes some $k$ priority preemptive priority $\left(p_{1}>p_{2}>, \ldots, p_{k}\right)$, for launch strategy goals, and other variables are defined as in MCGP. The proposal model bases the selection of the new product launch strategy $x_{j}$ on the TOPSISdetermined closeness coefficient $\left(C C_{j}\right)$ for corresponding $d_{i}^{+}$and $d_{i}^{-}$. The larger is $C C_{j}$, the more likely the corresponding launch strategy will be selected.

Notice that Eg. (21) actually represents a multiple goals model and cannot be solved by LP approaches, which consider only one objective at a time or all objectives are measured in the same units (such as dollars). However, an organization often has more than one objective and some objectives may relate to non-monetary objectives (Taylor 2004; Render et al. 2006). While GP is capable of handling decision problems involving multiple goals, if the problem belongs to a multiple choice objective, it becomes a MCGP problem that cannot be solved by LP approaches.

\section{Application of the model on new product launches strategy selection}

This study proposes an application of a new product launch strategy selection for a company to capture competitive advantages in the NPD process. To illustrate the application and the effectiveness of the proposed ANP, TOPSIS and MCGP models for new product launch strategy, a well-known manufacturer is introduced in this section as an example. The company Formosa Watch Co., Ltd. (FWCL) is a large, well-known manufacturer that sells watches in its own chain stores in Asia, It is not only the largest watch store in the Chinese world, but it is the largest watch chain store in the world. FWCL was founded in 1956 by C. F. Chen as a small watch shop. By 2005, FWCL had 354 chain stores and employed just over 2,350 people. In addition, FWCL products were being sold throughout China and Southeast Asia. In 2013, net sales were over \$125 million and after-tax profits were about $\$ 37$ million. For developing new products, in new market, Mr. Kevin Chen, president of the FWCL wanted to select the best new product launches strategy for foreign operations in order to achieve the competitive advantage in Southeast Asia. Therefore, international marketing managers and related experts in the FWCL were invited to define the new product launches strategy problem. 
Therefore, a committee of nine evaluators was invited to participate in this group and provide their opinions by using nominal group technique (NGT) (see Appendix). The evaluation criteria for new product launches strategy have been discussed in Section 2. Based on a literature review on the NGT, the decision-making group including experts who have rich experience in new product launches strategy was used to propose the criteria. The definition of criteria is presented in Table 2. The launch strategy evaluation process of the watch company is demonstrated as follows:

Step 1. After reviewing the literature and interviewing watch manufacturer practitioners, three launch strategies remained for further evaluation. A committee of nine evaluators, including manufacturer managers and experts, was formed to determine the most appropriate launch strategy. So, there is an interdependence relationship among criteria; the attribute of criterion TC are concerned with criteria MC and SC, and the attribute of criterion MM are concerned with criteria SC and NO. In addition, the attribute of criterion MC influences criteria SC and MM; the attribute of criterion MM influences criterion TC. In order to check net work structure or relationship in the considered criteria or candidate launch strategy, we need to have group discussion because the type of network or relationship depends on the DMs' judgement. Figure 3 presents the interdependence relationship among the evaluation criteria, which was determined by the committee in a thorough manner.

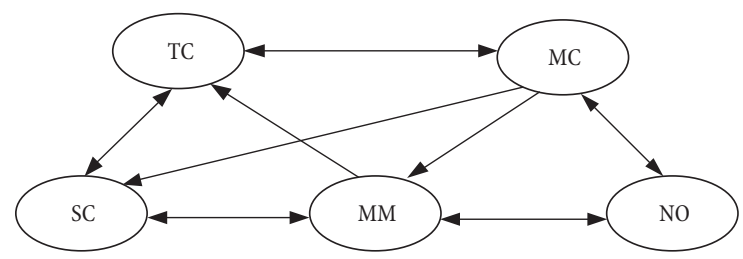

Fig. 3. The interdependence relationship among evaluation criteria: Market characteristic (MC), Social capital (SC); Technological capability (TC); New product development organization (NO) and Marketing mix (MM))

Step 2. The team members were asked to evaluate all proposed criteria (Table 2) pairwise without assuming interdependence among them. Generating a geometric mean of the evaluators' pairwise comparison values, the result is presented in Table 3 . The normalized weights matrix $\left(w_{1}\right)$ of criteria is as follows:

$$
\boldsymbol{w}_{1}=\left(\begin{array}{c}
\mathrm{MC} \\
\mathrm{SC} \\
\mathrm{MM} \\
\mathrm{NO} \\
\mathrm{TC}
\end{array}\right)=\left(\begin{array}{l}
0.244 \\
0.199 \\
0.182 \\
0.135 \\
0.241
\end{array}\right),
$$

which represents the related local priority of these criteria. 
Table 2. Proposed criteria and their related attributes

\begin{tabular}{|c|c|}
\hline Selection criteria & Evaluation attributes \\
\hline $\begin{array}{l}\text { Market characteristic (MC) } \\
\text { (Hultink, Robben 1999; Hsieh, Tsai 2007; } \\
\text { Chwastyk, Kołosowski 2014) }\end{array}$ & $\begin{array}{l}\text { Market growth/potential } \\
\text { The number of competitors } \\
\text { Firm performance }\end{array}$ \\
\hline $\begin{array}{l}\text { Social capital (SC) } \\
\text { (Uzzi 1996; Porter 1980; Hsieh, Tsai 2007; } \\
\text { Su, Rao 2011) }\end{array}$ & $\begin{array}{l}\text { Goodwill } \\
\text { Strategic alliance } \\
\text { External sources of financing } \\
\text { Research institutes, associations } \\
\text { Customer databases }\end{array}$ \\
\hline $\begin{array}{l}\text { Technological capability (TC) } \\
\text { (Lee et al. 2001; Lam et al. 2013; } \\
\text { Goodwin et al. 2014) }\end{array}$ & $\begin{array}{l}\text { Technicians count } \\
\text { R\&D count } \\
\text { Firm internal capital } \\
\text { Patents count } \\
\text { Closeness with foundries } \\
\text { Authorization numbers }\end{array}$ \\
\hline $\begin{array}{l}\text { New product development organization (NO) } \\
\text { (Robinson et al. 1992; Barczak 1995; } \\
\text { Su, Rao 2011; Goodwin et al. 2014) }\end{array}$ & $\begin{array}{l}\text { R\&D team } \\
\text { Project team } \\
\text { Product/marketing managers } \\
\text { Separate NP }\end{array}$ \\
\hline $\begin{array}{l}\text { Marketing mix (MM) } \\
\text { (Hultink et al. 1997; Chiu et al. 2006; } \\
\text { Gao et al. 2011; Goodwin et al. 2014) }\end{array}$ & $\begin{array}{l}\text { Branding } \\
\text { Number of channels } \\
\text { Distribution of expenditures } \\
\text { Penetration } \\
\text { Skimming } \\
\text { Promotion expenditures } \\
\text { Sales force intensity }\end{array}$ \\
\hline
\end{tabular}

Table 3. Criteria pairwise comparison matrix

\begin{tabular}{ccccccc}
\hline & MC & SC & MM & NO & TC & $w_{1}$ \\
\hline MC & 1 & 2.728 & 1.213 & 4.369 & 0.428 & 0.244 \\
\hline SC & 0.367 & 1 & 1.853 & 2.358 & 0.739 & 0.199 \\
\hline MM & 0.824 & 0.540 & 1 & 2.115 & 0.572 & 0.182 \\
\hline NO & 0.229 & 0.424 & 0.473 & 1 & 0.249 & 0.135 \\
\hline TC & 2.336 & 1.353 & 1.748 & 4.016 & 1 & 0.241 \\
\hline
\end{tabular}

Note: ${ }^{\star}$ Market characteristic (MC), Social capital (SC), Technological capability (TC), New product development organization (NO) and Marketing mix (MM).

Step 3. Next, we considered the interdependence among the evaluation criteria. The team members examined the impact of all criteria by using pairwise comparison. The normalized eigenvectors for these matrices are calculated and shown as five columns in Table 4, where zero was assigned to the eigenvector weights of the evaluation criteria that are independent. The value presented in Table 4 indicates the degree of the relative impact for each evaluation criterion. 
Table 4. The interdependence matrix of the evaluation criteria

\begin{tabular}{cccccc}
\hline $\boldsymbol{w}_{\mathbf{3}}$ & MC & SC & MM & NO & TC \\
\hline MC & 0.471 & 0.241 & 0.249 & 0.154 & 0.241 \\
\hline SC & 0 & 0.197 & 0.245 & 0.201 & 0.203 \\
\hline MM & 0.274 & 0.183 & 0.343 & 0.233 & 0.214 \\
\hline NO & 0.255 & 0.134 & 0.164 & 0.197 & 0.189 \\
\hline TC & 0 & 0.244 & 0 & 0.215 & 0.153 \\
\hline
\end{tabular}

Note: ${ }^{\star}$ Market characteristic (MC), Social capital (SC), Technological capability (TC), New product development organization (NO) and Marketing mix (MM).

Step 4. We now obtain the relative importance of the criteria considering interdependence. $\boldsymbol{w}_{\boldsymbol{c}}$ can be obtained by synthesizing the results from Steps 2 to $3: \boldsymbol{w}_{\boldsymbol{c}}=\boldsymbol{w}_{\mathbf{3}} \times \boldsymbol{w}_{\mathbf{1}}$; obtained market characteristic $(\mathrm{MC})=0.287$; social capital $(\mathrm{SC})=0.160$; marketing mix $(\mathrm{MM})=$ 0.248 ; new product development organization $(\mathrm{NO})=0.191$ and technological capability $(\mathrm{TC})=0.114$, shown as follows:

$$
w_{c}=w_{3} \times w_{1}=\left(\begin{array}{l}
0.287 \\
0.160 \\
0.248 \\
0.191 \\
0.114
\end{array}\right)
$$

Step 5. In this step of the decision procedure, evaluators were asked to establish the decision matrix by comparing the alternatives under each of the individual criteria. Moreover, all evaluators were asked to give a set of crisp value within the range from 1 to 10 to represent the performance of each alternative with respect to each criterion. After determining the decision matrix by using Eqs. (3) and (4), the normalized decision matrix of the new product launch strategy alternatives can be obtained as shown in Table 5.

Table 5. The weighted normalized decision matrix

\begin{tabular}{cccccc}
\hline $\boldsymbol{w}_{\boldsymbol{P}}$ & MC & SC & MM & NO & TC \\
\hline FE & 0.448 & 0.507 & 0.346 & 0.552 & 0.620 \\
\hline FF & 0.333 & 0.314 & 0.193 & 0.201 & 0.192 \\
\hline LE & 0.218 & 0.179 & 0.640 & 0.247 & 0.187 \\
\hline
\end{tabular}

Note: ${ }^{\star}$ The new product launch strategies such as $\mathrm{FE}=$ first entrant, $\mathrm{FF}=$ fast follower, and $\mathrm{LE}=$ late entrant to market.

In the meanwhile, the overall priorities for the candidate launch strategies $\boldsymbol{w}_{A N P}$ are calculated by multiplying $\boldsymbol{w}_{\boldsymbol{P}}$ by $\boldsymbol{w}_{\boldsymbol{c}}$. We have

$$
w_{A N P}=w_{P} \times w_{c}=\left(\begin{array}{l}
0.472 \\
0.254 \\
0.319
\end{array}\right) \text {. }
$$


Therefore, in Step 5, the results of the ANP method are (FE, FF, LE) $=(0.472,0.254$, $0.319)^{T}$, therefore, the first entrant (FE) launch strategy will have the highest weights value (0.472). Consideration to ANP method the FE will be selected.

Step 6. By using Eqs (5) and (6), the final ranking procedure should determine the ideal and negative-ideal solutions. Therefore, the ideal and negative-ideal solutions are determined as follows:

$$
\begin{aligned}
& A^{\star}=(0.448,0.507,0.640,0.552,0.620), \\
& A^{-}=(0.218,0.179,0.193,0.201,0.187) .
\end{aligned}
$$

By using Eqs (7), (8) and (9), the computed distances of each launch strategy to the ideal solution $\left(d_{i}^{*}\right)$ and the negative-ideal solution $\left(d_{i}^{-}\right)$, and the closeness coefficient $\left(C C_{i}^{*}\right)$ are presented in Table 6 . In Table 6 the later entry (LE) launch strategy will have the highest $C C_{i}^{*}$ value (0.434), therefore, when consideration to ANP and TOPSIS methods the LE will be selected.

Table 6. Computations of $d_{i}^{*}, d_{i}^{-}$and $C C_{i}^{*}$

\begin{tabular}{cccc}
\hline & $d_{i}^{*}$ & $d_{i}^{-}$ & $C C_{i}^{*}$ \\
\hline FE & 1.275 & 0.979 & 0.434 \\
\hline FF & 1.017 & 0.419 & 0.292 \\
\hline LE & 0.951 & 0.585 & 0.381 \\
\hline
\end{tabular}

Note: ${ }^{*}$ The new product launch strategies such as $\mathrm{FE}=$ first entrant, $\mathrm{FF}=$ fast follower, and $\mathrm{LE}=$ late entrant to market.

Step 7. The closeness coefficients $\left(C C_{i}, i=1,2,3\right)$ are obtained from Step 6 for each launch strategy. To formulate the MCGP model, we also build the specific criteria constraints and range of the launch strategy by FWCL in this model as shown in Table 7. Launch strategy weights are used as $C_{i}$ (e.g., $\mathrm{FE}=0.434, \mathrm{FF}=0.292, \mathrm{LE}=0.381$ ) in an objective function (e.g., $p_{2}\left(0.434 d_{6}^{-}+0.292 d_{7}^{-}+0.381 d_{8}^{-}\right.$in Table 8$)$ ) to allocate resources among the new product launch strategies. Based on the MCGP model formulation, the new product launch strategy selection problem was solved using LINGO (Schrage 2002) on a Pentium(R) 4 CPU $2.00 \mathrm{GHz}$-based microcomputer in a few seconds of computer time. The optimal solutions are as follows:

$$
\begin{aligned}
& x_{3}=1, x_{1}=x_{2}=0, \text { and } \\
& y_{1}=65000, y_{2}=7000, y_{3}=1250, y_{4}=18, y_{5}=8 .
\end{aligned}
$$

That is, the goals are fully satisfied, and $x_{3}=1$ denoted that the LE strategy will be selected. The MCGP model formulation to select a new product launch strategy is shown in Table 8. 
Table 7. Specific criteria of new launch strategies and value ranges

\begin{tabular}{cccccc}
\hline $\begin{array}{c}\text { Launch } \\
\text { strategies }\end{array}$ & $\begin{array}{c}\text { Product } \\
\text { advantage }\end{array}$ & $\begin{array}{c}\text { Marketing } \\
\text { expenditures }\end{array}$ & R\&D budgets & $\begin{array}{c}\text { Channel } \\
\text { numbers }\end{array}$ & $\begin{array}{c}\text { Sales force } \\
\text { numbers }\end{array}$ \\
\hline FE & 78000 & 10000 & 1500 & 23 & 8 \\
\hline FF & 80000 & 7500 & 1300 & 20 & 10 \\
\hline LE & 65000 & 7000 & 1200 & 18 & 12 \\
\hline Range & $63000 \sim$ & $5800 \sim 13000$ & $1250 \sim 1800$ & $15 \sim 25$ & $6 \sim 15$ \\
& 82000 & & & & \\
\hline
\end{tabular}

Table 8. MCGP model formulation to select a new product launch strategy

\begin{tabular}{|c|c|}
\hline MCGP model formulation & Goals \\
\hline \multicolumn{2}{|l|}{$\operatorname{Min} z=$} \\
\hline$p_{1}\left(\mathrm{~d}_{1}^{+}+\mathrm{e}_{1}^{+}+d_{2}^{-}+e_{2}^{-}+d_{3}^{-}+e_{3}^{-}+d_{4}^{+}+e_{4}^{+}+d_{5}^{-}+e_{5}^{-}\right)$ & Satisfy all obligatory goals \\
\hline$p_{2}\left(0.434 d_{6}^{-}+0.292 d_{7}^{-}+0.381 d_{8}^{-}\right)$ & $\begin{array}{l}\text { Select highest ANP weight NPD launch } \\
\text { strategy }\end{array}$ \\
\hline \multicolumn{2}{|l|}{ s.t. } \\
\hline $78000 x_{1}+80000 x_{2}+65000 x_{3}-d_{1}^{+}+d_{1}^{-}=y_{1}$ & $\begin{array}{l}\text { For product advantage goals: the more, } \\
\text { the better }\end{array}$ \\
\hline$y_{1}-e_{1}^{+}+e_{1}^{-}=63000$ & For $\left|y_{1}-g_{1, \max }\right|$ \\
\hline $63000 \leq y_{1} \leq 82000$ & For bound of $y_{1}$ \\
\hline $10000 x_{1}+7500 x_{2}+7000 x_{3}-d_{2}^{+}+d_{2}^{-}=y_{2}$ & $\begin{array}{l}\text { For marketing expenditures goals: } \\
\text { the less, the better }\end{array}$ \\
\hline$y_{2}-e_{2}^{+}+e_{2}^{-}=5800$ & For $\left|y_{2}-g_{2, \min }\right|$ \\
\hline $5800 \leq y_{2} \leq 13000$ & For bound of $y_{2}$ \\
\hline $1500 x_{1}+1300 x_{2}+1200 x_{3}-d_{3}^{+}+d_{3}^{-}=y_{3}$ & $\begin{array}{l}\text { For R\&D budget goals: the less, } \\
\text { the better }\end{array}$ \\
\hline$y_{3}-e_{3}^{+}+e_{3}^{-}=1250$ & For $\left|y_{3}-g_{3, \min }\right|$ \\
\hline $1250 \leq y_{3} \leq 1800$ & For bound of $y_{3}$ \\
\hline $23 x_{1}+20 x_{2}+18 x_{3}-d_{4}^{+}+d_{4}^{-}=y_{4}$ & $\begin{array}{l}\text { For channel number goals: the more, } \\
\text { the better }\end{array}$ \\
\hline$y_{4}-e_{4}^{+}+e_{4}^{-}=25$ & For $\left|y_{4}-g_{4, \max }\right|$ \\
\hline $15 \leq y_{4} \leq 25$ & For bound of $y_{4}$ \\
\hline $8 x_{1}+10 x_{2}+12 x_{3}-d_{5}^{+}+d_{5}^{-}=y_{5}$ & $\begin{array}{l}\text { For sales force number goals: } \\
\text { the less, the better }\end{array}$ \\
\hline$y_{5}-e_{5}^{+}+e_{5}^{-}=8$ & For $\left|y_{5}-g_{5, \min }\right|$ \\
\hline $6 \leq y_{5} \leq 15$ & For bound of $y_{5}$ \\
\hline$x_{1}+d_{6}^{-}=1$ & Select the FE launch strategy \\
\hline$x_{2}+d_{7}^{-}=1$ & Select the FF launch strategy \\
\hline$x_{3}+d_{8}^{-}=1$ & Select the LE launch strategy \\
\hline$d_{i}^{+}, d_{i}^{-}, e_{i}^{+}, e_{i}^{-} \geq 0, \quad i=1,2, \ldots, 6$ & \\
\hline
\end{tabular}


Step 8. According to the calculation result by using ANP in Step 5, first entrant (FE) launch strategy has the highest weights value (0.472), and by using ANP and TOPSIS methods in Step 6, FE launch strategy has still the highest weights value (0.434). In addition, the calculation result by using ANP, TOPSIS and MCGP methods in Step 7, the later entry (LE) launch strategy will be the best selection. The comparison of the findings of ANP, TOPSIS and MCGP about new product launch strategy and the others is shown in Table 9.

Table 9. Comparison of the findings of ANP, TOPSIS and MCGP

\begin{tabular}{|c|c|c|c|c|c|}
\hline \multirow{2}{*}{ New product launch strategy } & \multirow{2}{*}{ Results } & \multirow{2}{*}{ Rank } & \multicolumn{2}{|c|}{ Selection criteria } & \multirow{2}{*}{$\begin{array}{c}\text { Multi-choice } \\
\text { aspiration levels }\end{array}$} \\
\hline & & & Qualitative & Quantitative & \\
\hline ANP & & & Yes & No & No \\
\hline $\mathrm{FE}$ & 0.472 & 1 & & & \\
\hline FF & 0.254 & 3 & & & \\
\hline $\mathrm{LE}$ & 0.319 & 2 & & & \\
\hline ANP+TOPSIS & & & Yes & No & No \\
\hline $\mathrm{FE}$ & 0.434 & 1 & & & \\
\hline FF & 0.292 & 3 & & & \\
\hline LE & 0.381 & 2 & & & \\
\hline $\begin{array}{l}\text { This proposed method } \\
\text { (ANP+TOPSIS+MCGP) }\end{array}$ & & & Yes & Yes & Yes \\
\hline $\mathrm{FE}$ & 0 & & & & \\
\hline FF & 0 & & & & \\
\hline $\mathrm{LE}$ & 1 & & & & \\
\hline
\end{tabular}

\section{Discussions and conclusions}

When a firm is going to launch a new product, managers are always challenged with finding the proper strategy. The launch strategy adopted also determines whether a new product succeeds or fails. To achieve this business goal, DMs should apply the best method and accurate criteria to analyze and solve launch strategy selection problems. This paper illustrates how the ANP, TOPSIS and MCGP model would be implemented to help consumer goods manufacturers in NPD, which can be utilized in practice to determine the best launch strategy of a new product.

Collaborative evaluation technology is a popular method used in finding a solution to the problem of MCDM. One of the reasons for the popularity of ANP, TOPSIS and MCGP as an applicable method is the fact that it considers not only tangible and intangible criteria but also multi-choice aspiration levels. Given that many multiple-choice aspiration levels may exist in the real world, a multiple-choice method is most appropriate for a decision problem, which involves the evaluation of different criteria or attributes. First, the advantage of this current method is that it allows DMs to set multiple aspiration levels in the business resource allocation criteria. Second, the integrated approach appears to be an 
easily applicable method in finding a solution to the problem of how exactly to select a new product launch strategy for the NPD process. Moreover, the current method may be useful for various MCDM problems, including product position selection, promotion activities and business strategy, when available information is vague and uncertain. Therefore, the contribution or advantage of this integrated method is that it enables the consideration of both tangible (qualitative) and intangible (quantitative) criteria as well as both "more/ higher is better" (e.g., benefit criteria) and "less/lower is better" (e.g., cost criteria) in the launch strategy of a new product selection problem.

In addition, there are many techniques have been proposed to solve the MCDM problems. These approaches include LP, GP, TOPSIS, data envelopment analysis (DEA), cost point methods (CPM), AHP, ANP and fuzzy set theory. However, the modelling of many situations may not be sufficient or accurate, as the available data in real life are vague, inaccurate, imprecise and uncertain by nature.

Finally, there are many mathematical methods or transaction cost theories such as multisegment goal programming (MSGP) (e.g., Liao 2013b) group decision-making (GDM) (e.g., Fan et al. 2010), fuzzy MCDM (e.g., Baležentis et al. 2012), and fuzzy TOPSIS (e.g., Keršulienè, Turskis 2011) that can be combined or considered with the proposed integrated method in future research. These methods to practically implement a systematic structure for the determination process could easily be extended to the decision-making process for other marketing management problems. These methods can be the focus of future research for solving various managerial problems.

\section{References}

Ali, A.; Krapfel, R. J.; Labahn, D. 1995. Product innovativeness and entry strategy: impact on cycle time and break-even time, Journal of Product Innovation Management 12: 54-69. http://dx.doi.org/10.1111/1540-5885.t01-1-1210030

Aragon-Correa, A. L.; Sharma, S. 2003. A contingent resource-based view of proactive corporate environmental strategy, Academy of Management Review 28: 71-88. http://dx.doi.org/10.5465/AMR.2003.8925233

Baležentis, A.; Baležentis, T.; Misiūnas, A. 2012. An integrated assessment of Lithuanian economic sectors based on financial ratios and fuzzy MCDM methods, Technological and Economic Development of Economy 18(1): 34-53. http://dx.doi.org/10.3846/20294913.2012.656151

Barczak, G. 1995. New product strategy, structure, process, and performance in the telecommunications industry, Journal of Product Innovation Management 12: 224-234. http://dx.doi.org/10.1111/1540-5885.1230224

Banerjee, S.; Soberman, D. A. 2013. Product development capability and marketing strategy for new durable products, International Journal of Research in Marketing 30: 276-291. http://dx.doi.org/10.1016/j.ijresmar.2013.01.003

Biemans, W. G. 2003. A picture paints a thousand words: a critical look at B2B product development research, Journal of Business and Industrial Marketing 11(2): 134-146. http://dx.doi.org/10.1108/08858620310492392

Bowman, D.; Gatignon, H. 1995. Determinants of competitor response time to a new product introduction, Journal of Marketing Research 32(1): 42-53. http://dx.doi.org/10.2307/3152109

Bstieler, L. 2012. Perceived external uncertainty, new product development, and the timeliness of international product launch: a commentary essay, Journal of Business Research 65: 1346-1348.

http://dx.doi.org/10.1016/j.jbusres.2011.09.025 
Chang, C. T. 2008. Revised multi-choice goal programming, Applied Mathematical Modelling 32: 25872595. http://dx.doi.org/10.1016/j.omega.2005.07.009

Chang, C. T.; Chen, H. M.; Zhuang, Z. Y. 2014. Integrated multi-choice goal programming and multisegment goal programming for supplier selection considering imperfect-quality and price-quantity discounts in a multiple sourcing environment, International Journal of Systems Science 45(5): 11011111. http://dx.doi.org/10.1080/00207721.2012.745024

Charnes, A.; Cooper, W. W. 1961. Management model and industrial application of linear programming. New York: Wiley.

Chiu, Y. C.; Chen, B.; Shyuand, J. Z.; Tzeng, G. H.2006. An evaluation model of new product launch strategy, Technovation 26: 1244-1252. http://dx.doi.org/10.1016/j.technovation.2005.09.002

Cho, J.; Lee, J. 2013. Development of a new technology product evaluation model for assessing commercialization opportunities using Delphi method and fuzzy AHP approach, Expert Systems with Applications 40: 5314-5330. http://dx.doi.org/10.1016/j.eswa.2013.03.038

Chwastyk, P.; Kołosowski, M. 2014. Estimating the cost of the new product in development process, Procedia Engineering 69: 351-360. http://dx.doi.org/10.1016/j.proeng.2014.02.243

Cooper, R. G. 1985. Overall corporate strategies for new product programs, Industrial Marketing Management 14: 179-193. http://dx.doi.org/10.1016/0019-8501(85)90037-9

Cooper, R. G. 1994. New products: the factors that drive success, International Marketing Review 11(1): 60-76. http://dx.doi.org/10.1108/02651339410057527

Deng, H.; Robert, J. W.; Yeh, C. H. 2000. Inter-company comparison using modified TOPSIS with objective weight, Computer \& Operation Research 27(10): 963-973.

http://dx.doi.org/10.1016/S0305-0548(99)00069-6

Droge, C.; Calantone, R. 1996. New product strategy, structure, and performance in two environments, Industrial Marketing Management 25: 555-566.

http://dx.doi.org/10.1016/S0019-8501(96)00064-8

Easingwood, C. J.; Harrington, S. 2002. Launching and re-launching high technology products, Technovation 22: 657-666. http://dx.doi.org/10.1016/S0166-4972(02)00097-4

Ernst, H. 2002. Success factors of new product development: a review of the empirical literature, International Journal of Management Review 4(1): 1-40. http://dx.doi.org/10.1111/1468-2370.00075

Fan, Z. P.; Yue, Q.; Feng, B.; Liu, Y. 2010. An approach to group decision-making with uncertain preference ordinals, Computers \& Industrial Engineering 58: 51-57.

http://dx.doi.org/10.1016/j.cie.2009.08.001

Gao, Z.; Tang, L. 2003. A multi-objective model for purchasing of bulk raw materials of a large-scale integrated steel plant, International Journal of Production Economics 83(3): 325-334. http://dx.doi.org/10.1016/S0925-5273(02)00373-0

Gao, J.; Yao, Y.; Zhu, V. C. Y.; Sun, L.; Lin, L. 2011. Service-oriented manufacturing: a new product pattern and manufacturing paradigm, Journal of Intelligent Manufacturing 22: 435-461. http://dx.doi.org/10.1007/s10845-009-0301-y

Gatignon, H.; Weitz, B.; Bansal, P. 1990. Brand introduction strategies and competitive environments, Journal of Marketing Research 27(4): 390-401. http://dx.doi.org/10.2307/3172625

Chen, H.; Li, Y.; Liu, Y. 2015. Dual capabilities and organizational learning in new product market performance, Industrial Marketing Management 46: 204-213. http://dx.doi.org/10.1016/j.indmarman.2015.02.031

Ghodsypour, S. H.; O’Brien, C. A. 1998. A decision support system for supplier selection using an integrated analytic hierarchy process and linear programming, International Journal of Production Economic 56-57: 199-212. http://dx.doi.org/10.1016/S0925-5273(97)00009-1 
Ghodsypour, S. H.; O'Brien, C. A. 2001. The total cost of logistics in supplier selection, under conditions of multiple sourcing, multiple criteria and capacity constraint, International Journal of Production Economics 73(1): 15-27. http://dx.doi.org/10.1016/S0925-5273(01)00093-7

Goodwin, P.; Meeran, S.; Dyussekeneva, K. 2014. The challenges of pre-launch forecasting of adoption time series for new durable products, International Journal of Forecasting 30: 1082-1097. http://dx.doi.org/10.1016/j.ijforecast.2014.08.009

Griffin, A.; Page, A. L. 1993. An interim report on measuring product development success and failure, Journal of Product Innovation Management 10(4): 291-308. http://dx.doi.org/10.1016/0737-6782(93)90072-X

Guitinan, J. P. 1999. Launch strategy, launch tactics, and demand outcomes, Journal of Product Innovation Management 16(6): 509-529. http://dx.doi.org/10.1016/S0737-6782(99)00013-2

Guneri, A. F.; Yuceland, A.; Ayyildiz, G. 2009. An integrated fuzzy-lp approach for a supplier selection problem in supply chain management, Expert Systems with Applications 36(5): 9223-9228. http://dx.doi.org/10.1016/j.eswa.2008.12.021

Hsieh, M. H.; Tsai, K. H. 2007. Technological capability, social capital and the launch strategy for innovative products, Industrial Marketing Management 36: 493-502. http://dx.doi.org/10.1016/j.indmarman.2006.01.002

Hultink, E. J.; Griffin, A.; Hart, S.; Robben, H. S. J. 1997. Industrial new product launch strategies and product development performance, Journal of Product Innovation Management 14(1): 243-254. http://dx.doi.org/10.1111/1540-5885.1440243

Hultink, E. J.; Griffin, A.; Robben, H. S. J.; Hart, S. 1998. In search of generic launch strategies for new products, Journal of Product Innovation Management 15: 269-285. http://dx.doi.org/10.1016/S0167-8116(98)00004-4

Hultink, E. J.; Robben, H. S. J. 1999. Launch strategy and new product performance: an empirical examination in the Netherlands, Journal of Product Innovation Management 16: 545-556. http://dx.doi.org/10.1111/1540-5885.1660029

Hwang, C. L.; Yoon, K. 1981. Multiple attributes decision making methods and applications. New York: Springer. http://dx.doi.org/10.1007/978-3-642-48318-9

Kang, H. Y.; Lee, A. H. I.; Yang, C. Y. 2012. A fuzzy ANP model for supplier selection as applied to IC packaging, Journal of Intelligent Manufacturing 23: 1477-1488. http://dx.doi.org/10.1007/s10845-010-0448-6

Keršulienė, V.; Turskis, Z. 2011. Integrated fuzzy multiple criteria decision making model for architect selection, Technological and Economic Development of Economy 17(4): 645-666. http://dx.doi.org/10.3846/20294913.2011.635718

Kotler, P. 2003. Marketing management. 11ed. New Jersey: Prentice Hall.

Lam, P. Y.; Chan, A.; Gopaoco, H.; Oh, K.; So, T. H. 2013. Dual branding strategy for a successful new product launch in China, Business Horizons 56: 583-589. http://dx.doi.org/10.1016/j.bushor.2013.05.003

Lambkin, M. 1992. Pioneering new markets: a comparison of market share winners and losers, International Journal of Research in Marketing 9(1): 5-22. http://dx.doi.org/10.1016/0167-8116(92)90026-H

Lee, J. W.; Kim, S. H. 2000. Using analytic network process and goal programming for interdependent information system project selection, Computer \& Operation Research 27: 367-382. http://dx.doi.org/10.1016/S0305-0548(99)00057-X

Lee, C.; Leeand, K.; Pennings, J. M. 2001. Internal capabilities, external networks, and performance: a study on technology-based ventures, Strategic Management Journal 22(6/7): 615-640. http://dx.doi.org/10.1002/smj.181

Li, G. R.; Lin, C. J. 2014. New product adoption and sales performance from the importer perspective, Industrial Marketing Management (in press). http://dx.doi.org/10.1016/j.indmarman.2014.10.014 
Liao, C. N. 2013a. An evaluation model using fuzzy TOPSIS and goal programming for TQM consultant selection, Journal of Testing and Evaluation 41(1): 122-130. http://dx.doi.org/10.1520/JTE104563

Liao, C. N. 2013b. A fuzzy approach to business travel airline selection using an integrated AHPTOPSIS-MSGP methodology, International Journal of Information Technology \& Decision Making 12(1): 119-137. http://dx.doi.org/10.1142/S0219622013500065

Liao, C. N.; Kao, H. P. 2011. An integrated fuzzy TOPSIS and MCGP approach to supplier selection in supply chain management, Expert Systems with Application 38(9): 10803-10811. http://dx.doi.org/10.1016/j.eswa.2011.02.031

Lin, C. H.; Tsai, M. C. 2010. Location choice for direct foreign investment in new hospitals in China by using ANP and TOPSIS, Quality \& Quantity 44(2): 375-390. http://dx.doi.org/10.1007/s11135-008-9199-2

Lin, C. T.; Chen, C. B.; Ting, Y. C. 2011. An ERP model for supplier selection in electronics industry, Expert Systems with Applications 38(3): 1760-1765. http://dx.doi.org/10.1016/j.eswa.2010.07.102

Lockrey, S. 2015. A review of life cycle based ecological marketing strategy for new product development in the organizational environment, Journal of Cleaner Production 95: 1-15. http://dx.doi.org/10.1016/j.jclepro.2015.02.022

John, N. 2011. Using the Delphi technique in educational technology research, TechTrends 55(5): 24-30. http://dx.doi.org/10.1007/s11528-011-0524-6

Miles, R.; Snow, C. 1978. Organization strategy, structure, and process. New York: McGraw-Hill.

Nahapiet, J.; Ghoshal, S. 1998. Social capital, intellectual capital, and the organizational advantage, The Academy of Management Review 23(2): 242-266. http://dx.doi.org/10.5465/AMR.1998.533225

Önüt, S.; Kara, S. S.; Sik, E. 2009. Long term supplier selection using a combined fuzzy MCDM approach: a case study for a telecommunication company, Expert Systems with Applications 36(2): 3887-3895. http://dx.doi.org/10.1016/j.eswa.2008.02.045

Parry, M. E.; Song, X. M. 1994. Identifying new product success in China, Journal of Product Innovation Management 11(1): 15-30. http://dx.doi.org/10.1016/0737-6782(94)90116-3

Peng, Y.; Kou, G.; Wang, G.; Shi, Y. 2011. FAMCDM: a fusion approach of MCDM methods to rank multiclass classification algorithms, Omega 39: 677-689. http://dx.doi.org/10.1016/j.omega.2011.01.009

Porter, M. E. 1980. Competitive strategy: techniques for analyzing industries, and competitors. New York: The Free Press.

Render, B.; Stair-Jr, R. M.; Hanna, M. E. 2006. Quantitative analysis for management. 9 ed. New Jersey: Prentice Hall.

Robinson, W. T.; Fornell, C. 1985. Sources of market pioneer advantages in consumer goods industries, Journal of Marketing Research 22(3): 305-317. http://dx.doi.org/10.2307/3151427

Robinson, W. Y.; Forneel, C.; Sullivan, M. 1992. Are market pioneer intrinsically stronger than later entrants?, Strategic Management Journal 13: 609-624. http://dx.doi.org/10.1002/smj.4250130804

Romero, C. 2001. Extended lexicographic goal programming: a unifying approach, Omega 29: 63-71. http://dx.doi.org/10.1016/S0305-0483(00)00026-8

Saaty, T. L. 1996. Decision making with dependence and feedback: the analytic network process. Pittsbugrh: RWS Publications.

Saaty, T. L.; Vargas, L. G. 1998. Diagnosis with dependent symptoms: Bayes theorem and the analytic hierarchy process, Operational Research 46(4): 491-502. http://dx.doi.org/10.1287/opre.46.4.491

Schrage, L. 2002. LINGO Release 8.0. LINDO System, Inc.

Song, X. M.; Parry, M. E. 1997. A cross-national comparative study of new product development processes: Japan and the United States, Journal of Marketing 61(April): 1-18.

http://dx.doi.org/10.2307/1251827 
Song, L. Z.; Song, M.; Benedetto, C. A. D. 2011. Resources, supplier investment, product launch advantages, and first product performance, Journal of Operations Management 29: 86-104.

http://dx.doi.org/10.1016/j.jom.2010.07.003

Su, M.; Rao, V. R. 2011. Timing decisions of new product preannouncement and launch with competition, International journal of ProductionEconomics 129: 51-64. http://dx.doi.org/10.1016/j.ijpe.2010.09.001

Taylor, B. W. 2004. Introduction of management sciences. 8 ed. New Jersey: Prentice Hall.

Uzzi, B. 1996. The source and consequences of embeddedness for the economic performance of organizations: the network effect, American Sociological Review 61: 674-698. http://dx.doi.org/10.2307/2096399

Wu, W.; Kou, G.; Peng, Y.; Ergu, D. 2012. Improved AHP-group decision making for investment strategy selection, Technological and Economic Development of Economy 18(2): 299-316. http://dx.doi.org/10.3846/20294913.2012.680520

Wu, C. S.; Lin, C. T.; Lee, C. 2010. Optimal marketing strategy: a decision-making with ANP and TOPSIS, International Journal of Production Economic 127(1): 190-196.

http://dx.doi.org/10.1016/j.ijpe.2010.05.013

\section{APPENDIX}

The Nominal Group Technique (NGT) forces everyone to participate and no dominant person is allowed to come out and control the proceedings. In NGT, all ideas have equal stature and will be judged impartially by the group (Liao 2013a). The NGT procedure can be shorted four steps as: (a) silent generation of ideas in writing, (b) round-robin recording of ideas, (c) serial discussion of the list of ideas, and (d) take voting. NGT is applied in this paper; we have a set of $n$ criteria, $C=\left\{C_{1}, C_{2}, \ldots, C_{n}\right\}$ defined and described; with which green supplier performance is measured. Thus, criteria can be classified into two types as benefit criteria $C^{b}$ and cost criteria $C^{c}$. Then $C=C^{b} \cap C^{c}$ and $C^{b} \cap C^{c}=\varphi$, where $\varphi$ denote an empty set.

Chin-Nung LIAO is a Professor in Department of Business Administration, China University of Science and Technology. He holds a PhD degree of Management Sciences from Tamkang University, Taipei, Taiwan. In addition, He holds the second doctoral degree of Graduate Institute of Industrial Management, National Central University, Taoyuan, Taiwan. His major research interests are in marketing management, human systems management, human resources management, economics applications, and industrial management.

Chih-Hsiang LIN is an Associate Professor in the Department of Marketing and Distribution Management, Oriental Institute of Technology. He holds a $\mathrm{PhD}$ degree of Graduate Institute of Industrial Management, National Taiwan University of Science and Technology, Taipei, Taiwan. His major research interests are in Industrial management, human factor, marketing management, economy of cross-border e-commerce and technology applications, and service quality management.

Yan-Kai FU is an Associate Professor in Department of Business Administration, China University of Science and Technology. He holds a PhD degree of Public Administration and Public Policy from National Taipei University, Taipei, Taiwan. His major research interests are in economics applications, marketing research, organizational behaviour, and quantitative research methods. 